\title{
DNA Profile of Pacific White Shrimp, L. vannamei Infected by Taura Syndrome Virus Using Single Strand Conformation Polymorphism (SSCP) Analysis
}

\author{
Gusti Ngurah Permana ${ }^{1}$, Sari Budi Moria ${ }^{1}$, Ahmad Muzaki and Haryanti ${ }^{1}$ \\ ${ }^{1}$ Research Institute for Mariculture-Gondol, P.O. Box 140 SingarajaBali. \\ E-mail: gustipermana@gmail.com
}

\begin{abstract}
Gusti Ngurah Permana, Sari Budi Moria, Ahmad Muzaki and Haryanti. 2016. DNA Profile of Pacific White Shrimp, L. vannamei Infected by Taura Syndrome Virus Using Single Strand Conformation Polymorphism (SSCP) Analysis. Aquacultura Indonesiana, 17 (1): 1-6. The shrimp infected by Taura syndrome virus (TSV) can survive until harvesting time. At this phase, the growth of this shrimp is relatively normal but it is referred as TSV carrier. This research is expected to provide a recommendation in effort to prevent the occurrence of TSV infection. Therefore, this study was aimed to evaluate the DNA polymorhism of Pacific white shrimp L. vannamei infected by TSV. A total of 60 samples of L. vannamei were collected from SPF (specific pathogen free)-Florida, F1-healthy, F1-tolerance (it is can life normally after infected by TSV), and F1-moribund (diying after infected by TSV). The samples were analysis using PCR with IQ-2000 KIT to determine the positive infection of samples. DNA profile of white shrimp, L. vannamei was significantly different from SPF Florida, F1-moribund, and F1-healthy shrimp. This expression may control the defense mechanism. This can be ascribed to the reason that shrimp survived from TSV infection had a higher amount of locus (3 loci) that were detected from DNA polymorphism of gene in white shrimp contributed to a gene control that was determined from allele variation. Two important alleles (200 bp and $220 \mathrm{bp}$ ) unique may be associated with tolerant trait. Those loci only found in F1-tolerance shrimp. However to prove that further necessary to sequences a nucleotide of three loci as responsible for resistance to TSV infection.
\end{abstract}

Keywords : Taura syndrome virus; Tolerant; Litopenaeus vannamei; SSCP

\section{Introduction}

Pacific white shrimp, L. vannamei had a different defense mechanism system to virus invation and environmental changes. Nevertheless, shrimp infected by TSV in the reality in rearing pond can survive until harvesting time. At this phase, the growth of this shrimp is relatively normal but it is referred as TSV carrier (Lightner, 1995; Lightner and Redman, 1998). The performance of shrimp tolerance TSV had a pale, reddish colour on a telson (Figure 1). Studies on defense mechanism in the beginning were conducted based on analysis of haemocyte type characterization; however in the last two decades, studies on functional haemocyte (haemocyte? Should written consistently) characterization have been initiated (Hose et al., 1987 and Tsing et al., 1989). On the other hand, a study on DNA polymorphism is strongly important to complete the study of $L$. vannamei upon TSV infection.

DNA polymorphism based on PCR-SSCP analysis have potential tools to minimize the time, effort and more specific results. The fragments are separated by electrophoresis on polyacrylamide gel will form a pattern of DNA bands. In this technique, genomic DNA was amplified with a single primary (groups of $\sim 16$ nucleotides). In future the use of this molecular marker has the potential to be used as a marker related to important traits for aquaculture. Therefore, this study was aimed to observe the DNA polymorphism of $L$. vannamei upon TSV infection.

\section{Materials and Methods}

\section{Samples}

F0 samples with a certified Florida was conducted by diagnostic analysis using IQ 2000 kit to ensure that the shrimp were free of TSV virus. A total of 1,500 F1 shrimp were reared in the tank $\left(7 \mathrm{~m}^{3}\right)$. The samples were replicated in three tank. During the period (30 day) after infection, the moriband shrimp were collected for DNA analysis. A total of 60 shrimp samples were collected from SPF (specific pathogen free)Florida, F1 (Fillial)-healthy, F1-tolerance, and F1-moribund. The tolerace it can life normally till the end was used for DNA analysis. A citeria of tolerant animal is exposure to the pathogen (contamination); first stage of infection (local infection); systemic infection (elimination of the pathogen); clinical consequence (some expression of disease) and issue (some survival). A method used to determine these criteria in detail was seen in Figure 2. 

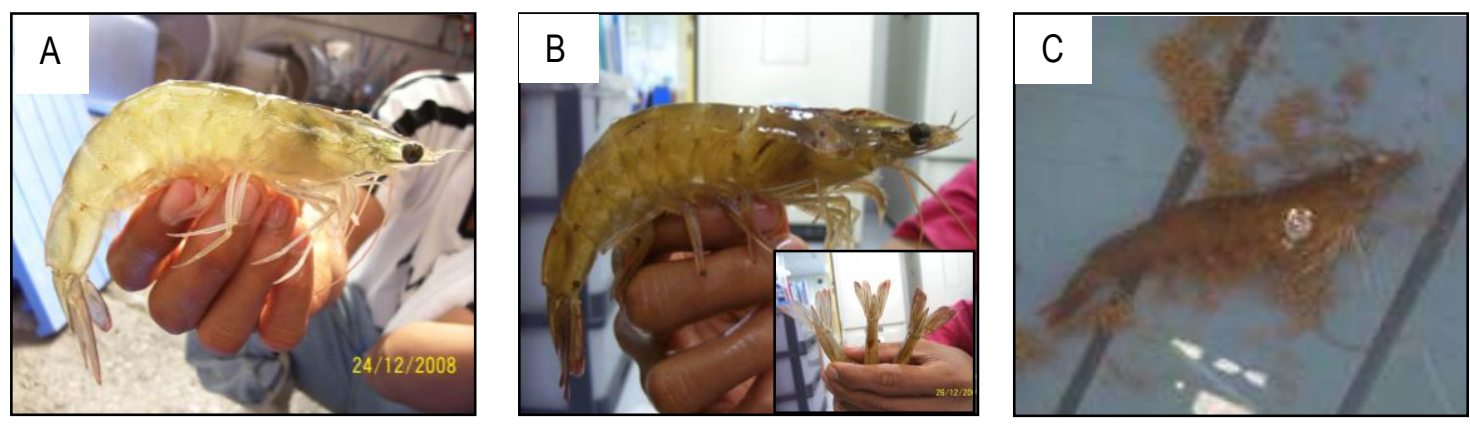

Figure 1. Pacific white shrimp healthy and SPF (A), infected by TSV (tolerant) (B), infected TSV (moribund) (C).

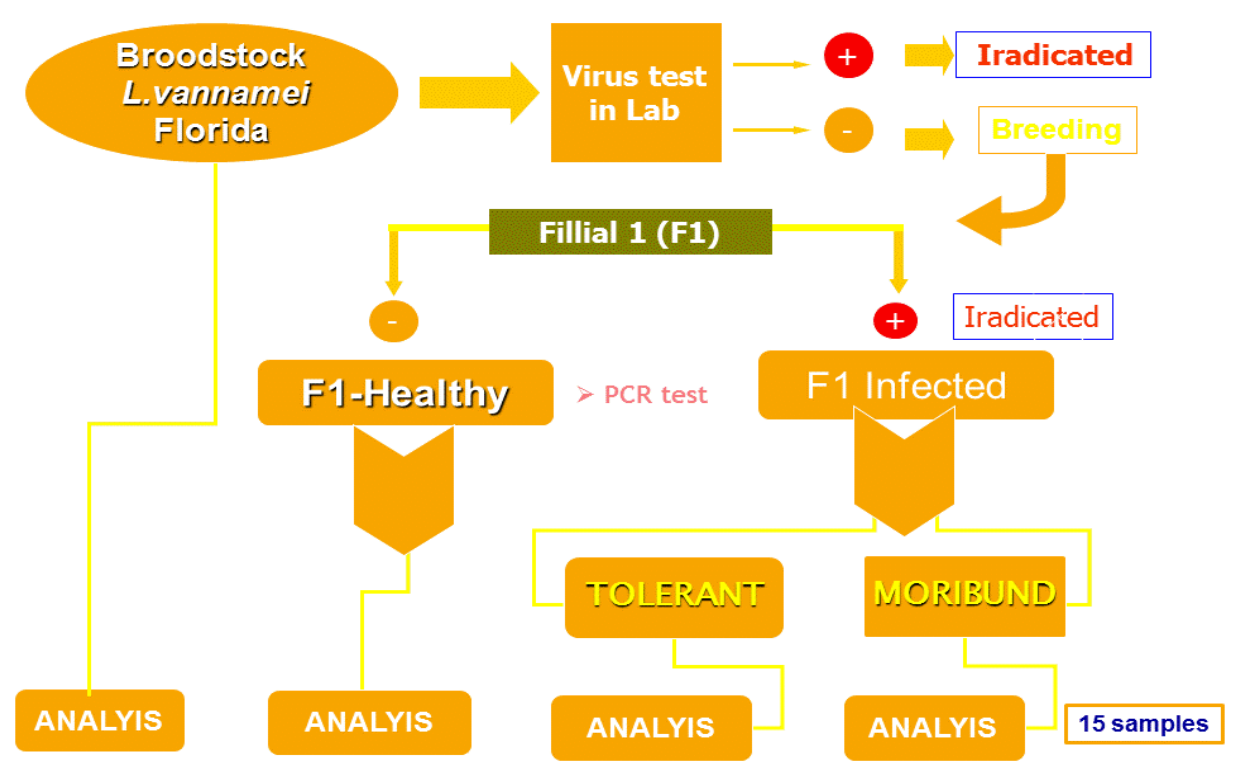

Figure 2. Schematic figure of experiment detail

\section{Materials}

The materials used are aquabidestilata, 10\% Chelex-100 (BIORAD), proteinases kinase (PK), DNA ladder 100 bp, genomic DNA, genome amplification results (PCR product), DNA purification kit (QIAquick PCR purification), genegel clean polyacrylamide, Qiagen kit, 2\% agarose, and DNA silver staining kit. Tools used include PCR plate, silica film, stopwatches, measuring cups, erlenmeyer, thermoblock (biometra), mixer tube (biofield), centrifuge (eppendorf $5415 \mathrm{R}$ ), autoclave (RKJ Ikemoto scientific-Tokyo), thermomixer compact (eppendorf), micropipet, eppendorf tubes, tips, engine speed cycler (analytic jena) and genephore electrophoretic machine (pharmacia biotech).

\section{DNA Extraction}

About $20 \mathrm{mg}$ of samples (meat) were taken and put into eppendorf tubes which already contained $10 \%$ of Chelex-100 in TE buffer $\mathrm{pH}$ $8.0250 \mu \mathrm{L}$. The samples were shoaked by hand and added PK (proteinase K) of $5 \mu \mathrm{L}$. Samples were incubated for 2.5 hours at $55^{\circ} \mathrm{C}$, and incubated again at $89^{\circ} \mathrm{C}$ for 8 minutes. Following centrifugation at $13,000 \mathrm{rpm}$ for 7 minutes was done. Layer formed on the supernatant was taken of about $200 \mu \mathrm{L}$ while the supernatant is known as genomic DNA.

DNA purification was carried out using QIAquick Purification Kit (Cat. No.28104 QIAGEN). A hundred $\mu \mathrm{L}$ of genome DNA was added $500 \mu \mathrm{L}$ binding buffer (PB), followed by vortex and flushing, and left for 5 minutes at room temperature. Furthermore, the solution is inserted into the QIAquick purification column and centrifuged at 13,000 rpm for 1 minute. The filtered solution was removed and added into the column wash buffer solution (PE) of $750 \mu \mathrm{L}$, then centrifuged for one minute with a speed of $13,000 \mathrm{rpm}$. The filtered solution was removed and collumn was centrifuged again with the same 
time and speed as previous. Lift the QIAquick column containing the filter and put into eppendorf tubes which had been sterile. The next stage of adding the solution of elution buffer (EB), which dropped as much as $30 \mu \mathrm{L}$ in the middle of the filter column and centrifuged at 13,000 rpm for one minute. Solution that has been filtered is pure genomic DNA with a high concentration.

The quantity of the extracted DNA were measured using Gene Quant RNA machinery/DNA calculator. Genome DNA was diluted 70 times using $\mathrm{ddH}_{2} \mathrm{O}$ and blank $\mathrm{ddH}_{2} \mathrm{O}$ DNA was calibrated at wavelength of 260 and $280 \mathrm{~nm}$. The sample was inserted into the cuvet and the DNA concentration $(\mu \mathrm{g} / \mathrm{mL})$ for each sample can be detected. If the level of DNA purity $(260 / 280 \mathrm{~nm}$ ratio $\lambda)$ was $\geq 1.7$ the detection will continued to amplification step.

\section{Amplification}

PCR amplification was performed using Tag DNA polymerase kit (promega) with composition of solution consisting of $\mathrm{ddH}_{2} \mathrm{O}: 4.1$ $\mu \mathrm{L}, 15 \mathrm{x}$ buffer: $2 \mu \mathrm{L}$, dNTPs $(10 \mathrm{~mm}): 0.2 \mu \mathrm{L}$, $\mathrm{MgCl}(25 \mathrm{mM}): 1.5 \mu \mathrm{L}$, primer sequences 2AAM2 (CTGCGA CCCAGAGCGG) : $1.0 \mu \mathrm{L}$, Tag polymerase: $0.2 \mu \mathrm{L}$, and genomic DNA: 1 $\mu \mathrm{L}$. Reagent solution was placed in a PCR plate and covered with a silica film and inserted into a speedy machine with a thermal cycler PCR shown in Table 1.

Table 1. Program thermal cycler of PCR amplification

\begin{tabular}{cccc}
\hline Reaction & Cycle & Temperature & Duration \\
\hline Initial & 1 & $95^{\circ} \mathrm{C}$ & $120 \mathrm{sec}$ \\
Denaturation & & & \\
Denaturation & & $95^{\circ} \mathrm{C}$ & $15 \mathrm{sec}$ \\
Annealing & 2 & $45^{\circ} \mathrm{C}$ & $15 \mathrm{sec}$ \\
Extention & & $70^{\circ} \mathrm{C}$ & $60 \mathrm{sec}$ \\
Denaturation & & $94^{\circ} \mathrm{C}$ & $5 \mathrm{sec}$ \\
Annealing & 38 & $45^{\circ} \mathrm{C}$ & $5 \mathrm{sec}$ \\
Extention & & $70^{\circ} \mathrm{C}$ & $30 \mathrm{sec}$ \\
Final extention & 1 & $70^{\circ} \mathrm{C}$ & $120 \mathrm{sec}$ \\
\hline
\end{tabular}

Results of PCR amplification was fragmented in agarose gel 2\% (SB buffer in 5\% Ethidium bromide). Electrophoresis with a constant electric current of 190 volts was performed for 35 minutes. Results of DNA fragment gel documented with Polaroid camera under UV transilluminator irradiation.

\section{SSCP analysis}

Polyacrilamide Gel (Clean Genegel Excel 15/24) was soaked in a solution of gel rehydration buffer on the container staining (staining dish) for 60 minutes. Gel was placed on a machine that is mediated with condensation Genephore $\mathrm{ddH}_{2} \mathrm{O}$ (about $3 \mathrm{~mL}$ ) to which chamber gel was not directly attached. Enam uL of PCR amplification product was inserted into the existing wells on the gel. Buffer strips and put up two sheets of moistened with electrode gel buffer solution about $1.5 \mathrm{~mL}$ of each strip, then put in buffer place functioned as a buffer bridge in which electric current can be flown. Fragmentation of genes in polyacrilamid gels was conditioned at a temperature of $15^{\circ} \mathrm{C}$ for 10 minutes at a constant voltage $200 \mathrm{v}, 12 \mathrm{~mA}$ and followed by 35 minutes on constant voltage time $600 \mathrm{~V}, 15 \mathrm{~mA}$ using gel electrophoresis Genephore. The next step was DNA staining with silver staining kit.

\section{Data analysis}

The gel images was analysis with gel BDA software. The exact test implemented in GENEPOP (Raymond and Rousset, 1995) and TFPGA (tools for population genetics analysis) version 1.3 A Windows ${ }^{\circledR}$ program for the analysis of allozyme and molecular population genetic data (Miller, 1997).

\section{Result}

DNA polymorhism of Pacific white shrimp with tolerance showed a higher amount of locus (3 loci). By contrast the shrimp F1-healthy, locus 3 was not expressed (Figure 3 ).

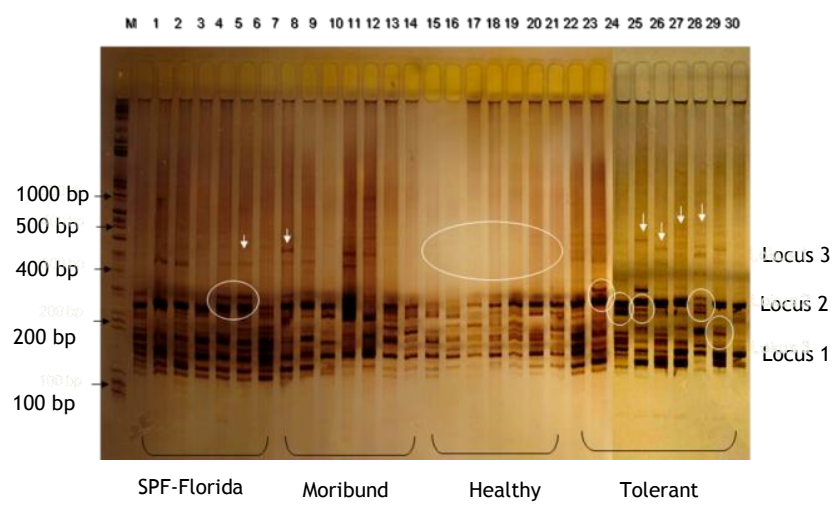

Figure 3: DNA polymorphism of the studied Pacific white shrimp Litopenaeus vannamei

\section{Allele frequency}

Allele frequency of survived shrimp with tolerance trait to TSV infection, SPF from Florida, offsprings shrimp (F1) healthy and F1moribund are shown in Table 2. 
Table 2. Allele frequencies of Pacific white shrimp with SPF trait Florida, offsprings (F1) healthy, F1 tolerant and F1 moribund of L. vannamei

\begin{tabular}{|c|c|c|c|c|c|c|c|c|c|}
\hline \multirow{2}{*}{ Locus } & \multirow{2}{*}{$\begin{array}{l}\text { Allele } \\
\text { (bp) }\end{array}$} & \multicolumn{2}{|c|}{ SPF-Florida } & \multicolumn{2}{|c|}{ F1-heathy } & \multicolumn{2}{|c|}{ F1-tolerant } & \multicolumn{2}{|c|}{ F1-moribund } \\
\hline & & $\begin{array}{l}\text { \#of } \\
\text { observation }\end{array}$ & Frequency & $\begin{array}{l}\text { \#of } \\
\text { observation }\end{array}$ & Frequency & $\begin{array}{l}\text { \#of } \\
\text { observation }\end{array}$ & Frequency & $\begin{array}{l}\text { \#of } \\
\text { observation }\end{array}$ & Frequency \\
\hline \multirow{9}{*}{1} & $120(1)$ & 12 & 0.40 & 11 & 0.37 & 15 & 0.66 & 7 & 0.23 \\
\hline & $130(2)$ & 3 & 0.10 & 1 & 0.33 & 2 & 0.07 & 5 & 0.17 \\
\hline & $135(3)$ & 0 & 0.00 & 4 & 0.13 & 1 & 0.03 & 8 & 0.27 \\
\hline & $140(4) * *$ & 3 & 0.10 & 1 & 0.03 & 0 & 0.00 & 0 & 0.00 \\
\hline & $145(5)$ & 2 & 0.06 & 1 & 0.03 & 0 & 0.00 & 6 & 0.20 \\
\hline & $150(6)$ & 0 & 0.00 & 6 & 0.20 & 4 & 0.13 & 2 & 0.07 \\
\hline & $155(7)$ & 1 & 0.03 & 3 & 0.10 & 3 & 0.10 & 0 & 0.00 \\
\hline & $165(8) * *$ & 7 & 0.23 & 3 & 0.10 & 0 & 0.00 & 0 & 0.00 \\
\hline & $170(9)^{*}$ & 2 & 0.06 & 0 & 0.00 & 0 & 0.00 & 0 & 0.00 \\
\hline \multirow{8}{*}{2} & $200(10)^{* * * *}$ & 9 & 0.30 & 7 & 0.23 & 13 & 0.43 & 0 & 0.00 \\
\hline & $205(11)$ & 6 & 0.20 & 4 & 0.13 & 9 & 0.30 & 8 & 0.27 \\
\hline & $210(12)$ & 3 & 0.10 & 7 & 0.23 & 1 & 0.03 & 3 & 0.10 \\
\hline & $220(13)^{* * *}$ & 3 & 0.10 & 4 & 0.13 & 7 & 0.23 & 0 & 0.00 \\
\hline & $240(14) * *$ & 1 & 0.03 & 6 & 0.20 & 0 & 0.00 & 0 & 0.00 \\
\hline & $252(15)$ & 4 & 0.13 & 2 & 0.06 & 0 & 0.00 & 1 & 0.03 \\
\hline & $272(16)^{*}$ & 2 & 0.07 & 0 & 0.00 & 0 & 0.00 & 0 & 0.00 \\
\hline & $275(17)^{*}$ & 2 & 0.07 & 0 & 0.00 & 0 & 0.00 & 0 & 0.00 \\
\hline \multirow{8}{*}{3} & $410(18)$ & 3 & 0.10 & 0 & 0.00 & 0 & 0.00 & 4 & 0.13 \\
\hline & 425 (19) & 6 & 0.20 & 0 & 0.00 & 11 & 0.45 & 10 & 0.33 \\
\hline & $450(20)$ & 5 & 0.17 & 0 & 0.00 & 1 & 0.04 & 6 & 0.20 \\
\hline & $500(21)$ & 2 & 0.06 & 0 & 0.00 & 1 & 0.04 & 3 & 0.10 \\
\hline & $510(22)^{* *}$ & 0 & 0.00 & 0 & 0.00 & 6 & 0.25 & 4 & 0.13 \\
\hline & $522(23)^{* *}$ & 0 & 0.00 & 0 & 0.00 & 5 & 0.20 & 2 & 0.06 \\
\hline & $530(24) *$ & 5 & 0.17 & 0 & 0.00 & 0 & 0.00 & 0 & 0.00 \\
\hline & $540(25)^{*}$ & 9 & 0.30 & 0 & 0.00 & 0 & 0.00 & 0 & 0.00 \\
\hline
\end{tabular}

Note : * (allel unique of SPF Florida), ** (allel unique of SPF and F1 healthy), *** (allel unique of tolerant trait)

Five of alleles $(20 \%)(170,272,275,530,540)$ were unique to the shrimp with SPF trait from Florida whereas six $(24 \%)$ of alleles $(140,165$, $240,272,510,522)$ were unique to SPF and F1 healthy. Two (8\%) of alleles (200 and 220) were unique to TSV tolerant shrimp. Among those alleles shared by SPF Florida and F1- healthy. Six alleles in locus 3 were absent in F1-healthy group.

Survival shrimp after infected by TSV had higher observation and allele frequencies (0.43). Moreover allele (220 and 510) were observed higher allele frequency (0.23 and 0.25$)$. Allele distributions of SPF florida, F1 healthy, F1 tolerant and F1 moribund is shown in Figure 4.

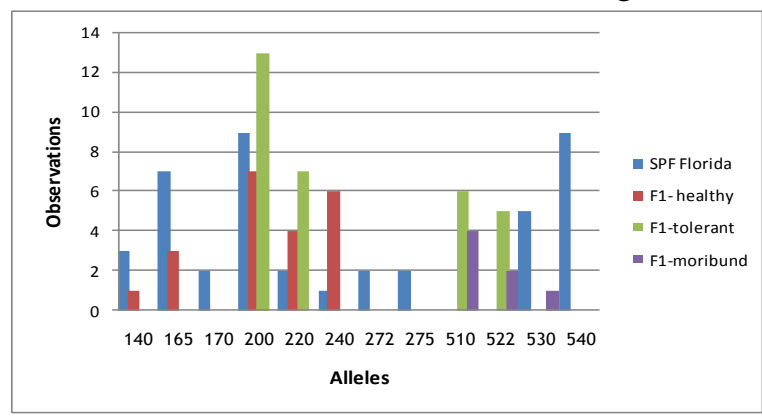

Figure 4. Allele distributions of SPF Florida, F1 healthy, F1 tolerant and F1 moribund of Pacific white shrimp L. vannamei

\section{Genetic variation}

Genetic variation determined from heterozygosity value of SPF shrimp from Florida, F1-healthy, F1-tolerant, F1-moribund was shown in Table 3. Genetic variations of $L$. vannamei (F1) tolerant TSV infection has a value 0.712 , filial (F1)-healthy (0.707), shrimp SPF from Florida has the highest value (0.753), while the lowest is the F1-moribund (0.623). The number of alleles per locus was equal to 7 of the F1healthy and F1-tolerant while the lowest is the F1-moribund (4.7).

The genetic distances constructed from similarity index (Rogers, 1972 and Nei, 1972) are shown in Figure 5. The genetic distances as shown in Figure 4 indicated that the genetic distance between F1-healthy and tolerant was 0.202 , this means nearly about $20 \%$ there is a difference of genotype constituent. Hereinafter both of them had a genetic distance $(0.255)$ to SPF-Florida and F1 moribund (0.272). 
Table 3. Summary of genetic variations on shrimp SPF from Florida, F1-healthy, F1-tolerant, and F1-moribund using DNA SSCP

\begin{tabular}{|c|c|c|c|c|}
\hline Parameter & SPF-florida & F1-healthy & F1-tolerant & F1-moribund \\
\hline Number of samples & 15 & 15 & 15 & 15 \\
\hline Number of locus & 3 & 2 & 3 & 3 \\
\hline No. of locus polymorhic & 3 & 2 & 3 & 3 \\
\hline No. of allele per locus & 10 & 7 & 7 & 4.7 \\
\hline \multicolumn{5}{|l|}{ Heterozyosity } \\
\hline Locus 1 & 0.797 & 0.704 & 0.705 & 0.522 \\
\hline Locus 2 & 0.664 & 0.711 & 0.713 & 0.666 \\
\hline Locus 3 & 0.797 & 0.000 & 0.720 & 0.680 \\
\hline Average & 0.753 & 0.707 & 0.712 & 0.623 \\
\hline & & & \multicolumn{2}{|c|}{ F1-healthy } \\
\hline & & & \multicolumn{2}{|c|}{ F1-tolerant } \\
\hline & & & \multicolumn{2}{|c|}{ SPF Florida } \\
\hline & & & \multicolumn{2}{|c|}{ F1-moribund } \\
\hline 7 & & & & \\
\hline 0.300 & 0.200 & .100 & & \\
\hline
\end{tabular}

Figure 5. Dendrogram of genetic distances of SPF shrimp from Florida, (F1)-healthy, tolerant and moribund.

\section{Discussion}

\section{Genetic Differentiation}

DNA expression of white shrimp, $L$. vannamei tolerant was significantly different with SPF Florida, F1-moribund, and F1-healthy shrimp. The most frequent alleles at survived shrimp after infected TSV were unique to each of tolerant traits. This expression may control the defense mechanism. This can be ascribed to the reason that shrimp survived from TSV infection had a higher amount of locus (3 loci) that were detected. Genetic differentiation between SPF Florida and offsprings could be a consequence of the implementation of the hatchery, from which important alleles may be lost in the breeding process. But in the shrimp infected TSV, the locus 3 was expressed as an act or ability to detect foreign matter. Several new alleles were found in the group of tolerant TSV infection with various amounts. This is apparently an expression of the shrimp's body as a reaction to TSV infection. SSCP technique can be used to separate DNA molecules of changes in one nucleotide bases (Sheffield et al., 1990).

Genetic variation in a living organism can be arised due to mutation, natural selection, environmental influences and breeding.
Populations with high genetic variation will have a higher living chance to adapt to environmental changes. Meanwhile, low genetic variation would be undermine the resilience of individuals to environmental changes and disease infections (Haryanti et al., 2004).

The closest value of genetic distances (0.202) were observe on F1 healthy and F1tolerant, while both of them Both long distance with SPF-Florida (0.255) and F1 moribund (0.272). We thought that some genetic characteristics were different between tolerant to TSV infection group compared to moribund shrimp. Performance of genetic expression may be caused by mutations or changes in the composition of the DNA sequence. At the basic or gene level, genetic variation is continuously increased by mutation, which produces new allelic variants.

\section{Possible Associated Marker for TSV Resistance}

Association between polymorphic fingerprint DNA, microsatellite or other molecular marker and important phenotypic traits had been studied. MI alleles (237, 220, 218,215, 207, 206, 200, 197, 190, 189, and 187bp) may be associated with TSV resistance or susceptibility in shrimp. MI alleles were unique to the Select 
line (Gross and Nilsson, 1999; Sharif et al., 1998; $\mathrm{Xu}$ et al., 2003). This research was found that two important alleles (200 and 220) unique may be associated with tolerant trait.

To find molecular markers related with the character of tolerant TSV, it is necessary to sequence to indicate the existence of a strong correlation of markers with the trait. A large number of molecular markers should be screened to find a potentially useful marker for MAS (marker assisted selection). Breeding for TSV resistance is expected to influence other fitness traits as well, it appears that breeding for a single trait should be carefully examined when planning selective breeding programs.

\section{Conclusions}

DNA polymorphism of L. vannamei which tolerance trait was contributed to a gene control, that were determined from allele variation. This different polymorphic expression may be caused by mutation, deletion, or dissimilar insertion gene. Two important alleles (200 bp and 220 bp) unique may be associated with tolerant trait, However to prove this phenomena it is necessary to sequences a nucleotide as responsible for resistance trait on TSV infection.

\section{Acknowledgements}

We would like to thanks to Prof. Dr. Rustidja, M.S. (Brawijaya University) for his advice and support with genetics and immunology study of shrimp. Finally thanks to all technicians of the biotechnology laboratory and tuna hatchery.

\section{References}

Gross, R. and J. Nilsson. 1999. Restriction fragment length polymorphism at the growth hormone I gene in Atlantic salmon (Salmon salar L.) and its associated with weight among the offspring of a hatchery stock. Aquaculture, 173:73-80.

Haryanti, S.B. Moria, and G.N. Permana. 2004. Genetic diversity and Fry quality of Pacific white shrimp, Litopenaeus vannamei. Proceeding Seminar National Biology FMIPA ITS, Surabaya. pp.1-6.

Hose, J.E., G.G. Martin, V.A. Nguyen, J. Lucas, and T. Rosenstein. 1987. Cytochemical features of shrimp haemocytes. Biological Bulletin, 173, 178-187.

Lightner, D.V. 1995. Taura Syndrome: An economically important viral disease impacting the shrimp farming industries of the Americas including the United States. In: Proceedings of the nine-ninth annual Meeting, Reno, Nevada. Pat Campbell \& Associates, Richmond, Virginia, USA. pp. 36-52.

Lightner, D.V. and R.M. Redman. 1998. Strategies for the control of viral diseases of shrimp in the Americas. Fish Pathol., 33, p 165-180.

Miller, M.P. 1997. Tools for Population Genetic Analyses (TFPGA) version 1.3. A Windows $®$ program for the analysis of allozyme and molecular population genetic data Department of Biological Sciences - Box 5640. Northern Arizona University Flagstaff, AZ 86011-5640 mpm2@jan.ucc.nau.edu.29 pp.

Raymond, M. and F. Rousset. 1995. GENEPOP, version 1.2. Population genetics software for exact test and ecumenicism. Journal of Heredity, 86: 248-249.

Rogers, J.S. 1972. Measures of genetic similarity and genetic distance. Pp. 145-153. In : Studies in genetics. VII. Ed., M.R. Wheeler. Univ. Texas Publ., 7213. 354p.

Tsing, A., J.M. Arcier, and M. Brehélin. 1989. Haemocytes of penaeid and palaemonid shrimps: morphology, cytochemistry, and hemograms. Journal of Invertebrate Pathology, 53, 64-77.

Nei, M, 1972. Genetic distance between population. Am. Nat $06: 283-292$.

Sheffield, V.C., D.R. Cox and R.M. Myers. 1990. Identiyfying DNA polymorphism by denaturing gradient gel electrophoresis. In : Innis, M.A., Gelfand, D.H., Sninsky, JJ., and White, T.J. (Eds.) PCR Protocols. A Guide to Methods and Amplifications. Academic Press, Inc. San Diego.pp.

Sharif, S., B.A. Mallard, B.N. Wilkie, J.M. Sargeant, H.M. Soctt, J.C.M. Dekkers, and K.E. Leslie. 1998. Associations of the bovine major histocompatibility complex DRB3 (BoLA-DRB3) with production traits in Canadian dairy cattle. Animal Genetics, 30: 157-160.

Xu, Z., J. Wyrzykowski, A.A. Warren, B.J. Argue, S.M. Moss, S.M. Arce, M. Traub, F.R.O. Calderon, J. Lotz, V. Breeland. 2003. Genetics analysis for TSV-susceptible and TSV-resistant Pacific White Shrimp, Litopenaeus vannameiI using M1 Microsatellite. Journal of Aquaculture Society, 34: 332-343. 